\title{
Studi Elektrostatik Elektroda Runcing dan Aplikasinya pada Perangkat Floating Gate Memory
}

\author{
Fatimah Arofiati Noor ${ }^{1, *}$, Gilang Mardian Kartiwa1, Muhammad Amin Sulthoni² \\ ${ }^{1}$ Kelompok Keahlian Fisika Material Elektronik, Program Studi Fisika, Fakultas Matematika dan Ilmu \\ Pengetahuan Alam, Institut Teknologi Bandung., Jl. Ganesa no. 10 Bandung 40132 \\ ${ }^{2}$ Kelompok Keahlian Elektronika, Sekolah Teknik Elektro dan Informatika, Institut Teknologi Bandung., Jl. \\ Ganesa no. 10 Bandung 40132 \\ *Email : fatimah@fi.itb.ac.id \\ (Diterima 09 Februari 2021; Disetujui 18 Juli 2021; Dipublikasikan 15 Oktober 2021)
}

\begin{abstract}
Abstrak
Pada penelitian ini, potensial elektrostatik dari struktur floating gate runcing dalam sel memori split gate dipelajari secara analitik dan numerik. Penelitian ini bertujuan memberikan pendekatan sederhana untuk mempelajari diagram pita energi pada perangkat memori. Diagram energi yang dihasilkan dapat digunakan untuk mempelajari transmitansi elektron dan rapat arus terobosan. Pada studi ini, floating gate runcing dimodelkan sebagai elektroda berbentuk segitiga. Profil potensial elektrostatik elektroda segitiga ini dihitung secara analitik dengan menyelesaikan nilai batas dari persamaan Laplace dalam koordinat polar. Profil potensial dari perhitungan analitik ini lalu dibandingkan dengan profil potensial dari simulasi numerik. Dari hasil perhitungan diperoleh bahwa profil diagram energi yang dihitung secara analitik cukup sesuai dengan yang diperoleh dari simulasi numerik. Adapun terdapat sedikit perbedaan antara profil diagram pita analitik dan numerik dikarenakan elektroda segitiga diasumsikan terbuat dari logam sehingga pembentukan sumur kuantum pada permukaan floating gate diabaikan. Dari hasil permodelan analitik diperoleh bahwa sumur kuantum yang terbentuk pada tegangan sekitar $10 \mathrm{~V}$ (sesuai dengan tegangan hapus perangkat memori flash) adalah cukup dangkal, sehingga profil potensial yang terbentuk menjadi sangat mendekati hasil simulasi numerik. Dari hasil perhitungan diperoleh pula bahwa rapat arus terobosan yang dihitung menggunakan model kami memberikan hasil yang sangat dekat dengan hasil perhitungan dari model injektor silinder yang digunakan oleh peneliti dari Silicon Storage Technology (SST) sebagai produsen produk flash memory dengan floating gate berbentuk runcing.
\end{abstract}

Kata kunci: arus terobosan, elektroda runcing, elektrostatika, potensial penghalang

\section{Latar Belakang}

Sejak pertama kali ditemukan pada tahun 1959, perangkat semikonduktor dengan struktur logam-oksida-semikonduktor (MOS) (contohnya Perangkat MOSFET dan CMOS) telah mengalami banyak perkembangan dalam hal variasi struktur. Salah satu inovasi terpenting adalah floating gate MOS (FGMOS) yang pertama kali diperkenalkan oleh Kahng dan Sze [1]. Jenis struktur ini menyediakan beberapa fungsi khusus, salah satunya adalah sebagai penyimpanan muatan. Kemampuan dalam menyimpan muatan ini dikarenakan floating gate dihimpit di antara dua isolator sehingga menjadi terisolasi secara elektrik (merujuk pada istilah "floating"), yang membuat struktur floating gate dapat menahan muatan. Karena perilaku tersebut, FGMOS dapat menunjukkan kurva arus-tegangan yang berbeda tergantung dari seberapa banyak muatan yang tersimpan dalam floating gate [2].

Sifat perangkat berbasis floating gate yang memiliki lebih dari satu kurva arus-tegangan ini memungkinkannya untuk digunakan sebagai perangkat penyimpanan data. Untuk memperoleh kemampuan menyimpan data (misalnya perangkat memori), muatan harus ditransfer terlebih dahulu ke dalam dan ke luar struktur floating gate; semua proses ini masing-masing dinamakan pemrograman dan penghapusan. Proses pemrograman dan penghapusan dapat terjadi dengan memanfaatkan berbagai jenis fenomena fisika, salah satunya adalah terobosan kuantum. Terobosan kuantum telah digunakan oleh para peneliti untuk tujuan pemrograman [3] dan penghapusan [4]. Terdapat beberapa jenis mekanisme terobosan yang digunakan dalam perangkat memori. Dalam struktur MOS saja, mungkin terjadi sebanyak delapan mekanisme terobosan yang berbeda [5]. Salah satu model terobosan terpenting yang digunakan dalam konteks pemrograman atau proses penghapusan dalam perangkat memori adalah terobosan Fowler-Nordheim [6], yaitu sebuah fenomena terobosan melalui penghalang segitiga biasa atau segitiga dengan ujung tumpul [7]. Dalam struktur FGMOS planar, kerapatan arus terobosan melalui 
oksida yang ditumbuhkan secara termal dapat dinyatakan oleh persamaan Fowler-Nordheim [8]:

$$
J=A \phi^{-1} F^{2} \exp \left(-\frac{B \phi^{3 / 2}}{F}\right)
$$

dengan A dan B merupakan konstanta universal, $\phi$ adalah fungsi kerja lokal, dan $F$ adalah medan listrik lokal di titik injeksi.

Saat terjadi miniaturisasi perangkat, ketebalan oksida akan berkurang dan membuatnya rentan terhadap degradasi yang disebabkan oleh tingginya medan listrik yang umumnya digunakan dalam proses penghapusan flash memory. Degradasi ini dapat menyebabkan arus bocor, yang dapat menimbulkan sejumlah masalah pada perangkat memori seperti gangguan proses pembacaan [9], proses pemrograman /penghapusan yang lebih lambat, serta retensi data yang buruk [10]. Menurut Mozzami dan $\mathrm{Hu}$ [11], arus bocor berasal dari proses terobosan disertai perangkap muatan dimana kerapatan perangkap yang dihasilkan dalam oksida meningkat seiring dengan bertambahnya medan listrik dan penurunan ketebalan oksida.

Salah satu inovasi dalam mengatasi masalah kebocoran arus adalah dengan ditemukannya struktur floating gate runcing oleh Silicon Storage Technology (SST) yang bernama SuperFlash ${ }^{T M}$. Dalam kondisi yang sama, struktur runcing ini akan memunculkan medan listrik yang lebih besar daripada struktur planar akibat adanya konsentrasi muatan di bagian ujung runcing. Perilaku muatan ini menyebabkan penurunan penghalang potensial secara non-linear seperti yang diilustrasikan secara skematis pada Gambar 1 (B).

Akibatnya, untuk ketebalan oksida dan tegangan bias yang sama, elektron pada permukaan floating gate runcing akan "berhadapan" dengan penghalang potensial yang lebih tipis sehingga meningkatkan probabilitas terobosan kuantum. Hal ini membuat perangkat memori berbasis struktur runcing dapat tetap mempertahankan penggunaan

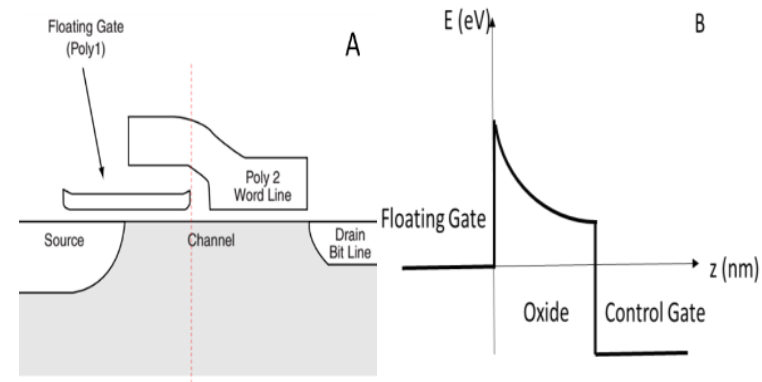

Gambar 1. Struktur SuperFlash ${ }^{\mathrm{TM}}$ generasi pertama SSF (A), dan diagram profil pita-konduksi di sepanjang garis merah dalam (A) selama proses penghapusan (B). lapisan oksida yang tebal (sehingga lebih tahan terhadap degradasi akibat pengaplikasian tegangan tinggi). Studi tentang perangkat SuperFlash ${ }^{\mathrm{TM}}$ pernah dilakukan oleh para penemu SST [12-15]. Namun, studi-studi tersebut hanya terfokus pada perilaku kurva $I_{\mathrm{d}}-V_{\mathrm{g}}$ setelah pemrograman dan penghapusan serta perilaku retensi. Sampai saat ini belum pernah ada studi khusus yang fokus pada perilaku diagram pita energi floating gates runcing. Penelitian ini bertujuan untuk mempelajari diagram pita energi dari struktur floating gate runcing dengan cara memodelkannya sebagai elektroda logam berbentuk segitiga, untuk kemudian dihitung arus terobosannya. Pendekatan ini juga dapat digunakan untuk memodelkan jenis perangkat lain yang memiliki fitur ujung runcing, dan telah digunakan untuk sejumlah aplikasi dari simulasi FinFET [16], pemodelan antena slot [17], dan lainnya.

\section{Metodologi}

Dalam model kami, diasumsikan bahwa gate (gerbang) terbuat dari bahan polisilikon $\mathrm{n}^{+}$dan oksida tidak memiliki perangkap muatan. Untuk menentukan distribusi potensial antara floating gate dan gate control, digunakan syarat batas permukaan. Dalam pendekatan ini (ditunjukkan oleh Gambar 2), kami hanya memodelkan bagian floating gate yang runcing serta gate control (ditandai oleh poli 2 pada Gambar 2) yang dimodelkan sebagai struktur planar dengan mengabaikan bagian vertikalnya. Model ini biasa digunakan untuk memodelkan perangkat dengan bentuk runcing seperti scanning tunneling microscopy atau tunneling diodes [18].

Dalam pemodelan kami, digunakan nilai batas sebagai berikut:

$$
\varphi=\left\{\begin{array}{cc}
0 & ; \text { sepanjang permukaan cone } \\
1 & ; \text { sepanjang elektroda datar }
\end{array},\right.
$$

$$
\nabla^{2} \varphi=0
$$

dengan $\varphi$ merupakan potensial listrik dan $F$ adalah medan listrik, yang dapat diekstrak secara langsung (dengan asumsi sistem koordinat Cartesius) dari:

$$
F=-\frac{\partial \varphi}{\partial z}
$$

Dengan mengetahui distribusi potensial di sepanjang sumbu-z, profil pita energi konduksi dapat dihitung sebagai berikut [19]:

$$
U_{(z)}=\Phi_{F G}-\chi_{I}-e \varphi_{(z)}
$$


dimana $\Phi_{F G}$ dan $\chi_{I}$ adalah fungsi kerja dari material floating gate dan afinitas elektron dari isolator.
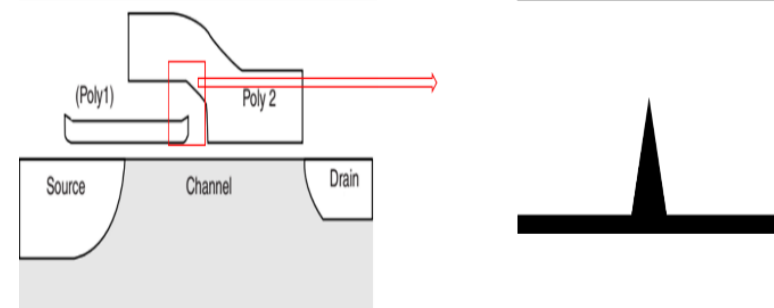

Gambar 2. Model sederhana dari ujung floating gate (ditandai dengan poli 1) dan gate control (poli 2).

Hasil yang diperoleh adalah profil potensial penghalang yang kemudian dapat digunakan untuk mempelajari rapat arus terobosan. Rapat arus terobosan di sepanjang sumbu-z $\quad\left(U_{z}\right)$ dapat ditentukan dengan mengevaluasi eksponen Gamov, $G$, terlebih dahulu [7],

$$
G=g_{e} \int \sqrt{U_{(z)}-E_{z}} d z
$$

dimana $g_{e}$ adalah konstanta Jeffreys-WentzelKramers-Brillouin. Kemudian, $J_{z}$ akan dievalusi berdasarkan:

$$
\begin{gathered}
J_{z}=\frac{2 e}{h} \int_{-\infty}^{\infty} \exp (-G)\left[f\left(E_{z}\right)-f\left(E_{z}\right.\right. \\
\left.\left.+e V_{B}\right)\right] d E_{z}
\end{gathered}
$$

Distribusi potensial dan profil energi konduksi yang dihitung menggunakan persamaan tersebut kemudian akan dibandingkan dengan hasil numerik. Simulasi numerik dilakukan menggunakan SYNOPSYS Sentaurus. Secara khusus, kami menggunakan Sentaurus Structure Editor untuk membangun model seperti yang ditunjukkan pada Gambar 2 dan perangkat Sentaurus untuk menyelesaikan persamaan Laplace dengan syarat batas yang diberikan.

\section{Hasil}

Sharp floating gate dimodelkan sebagai elektroda segitiga seperti yang ditunjukkan pada Gambar 3.

Dengan menggunakan koordinat polar, untuk titik $\mathrm{P}$ sembarang pada jarak $r$ dari atas titik, potensial listrik dinyatakan oleh persamaan Laplace yang berbentuk:

$$
\frac{1}{r} \frac{\partial}{\partial r}\left(r \frac{\partial \varphi}{\partial r}\right)+\frac{1}{r^{2}} \frac{\partial^{2} \varphi}{\partial \phi^{2}}=0
$$

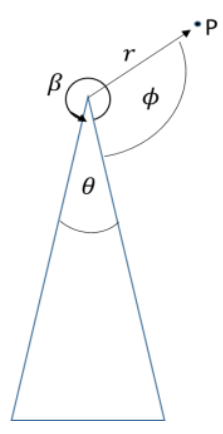

Gambar 3. Pemodelan tepian floating gate.

Dengan menggunakan pemisahan variabel, yaitu:

$$
\varphi_{(r, \phi)}=R_{(r)} \Phi_{(\phi)}
$$

diperoleh solusi untuk $R_{(r)}$ dan $\Phi_{(\phi)}$ dengan menggunakan persamaan berikut:

$$
\begin{gathered}
\Phi=\left\{\begin{array}{cc}
a_{0} & ; n=0 \\
a_{n} \sin (n \phi)+b_{n} \cos (n \phi) & ; n=1,2, . .
\end{array}\right. \\
R=\left\{\begin{array}{lc}
a_{0}+b_{0} \ln r & ; n=0 \\
a_{n} r^{n}+b_{n} r^{-n} & ; n=1,2, \ldots
\end{array}\right.
\end{gathered}
$$

Dengan menggabungkan persamaan (9) dan (10) serta menggabungkan semua konstanta, maka diperoleh solusi sebagai berikut:

$$
\begin{aligned}
& \varphi_{(r, \phi)} \\
& =a_{0}+b_{0} \ln r+\sum_{n=1}^{\infty} a_{n} r^{n} \sin (n \phi) \\
& +\quad \sum_{n=1}^{\infty} b_{n} r^{-n} \cos (n \phi)
\end{aligned}
$$

Dengan menggunakan syarat batas dan melakukan penjumlahan pada orde pertama [20], serta mengganti parameter $r$ menjadi $z / d$ [21], maka diperoleh persamaan berikut:

$$
\varphi_{(r, \phi)}=V\left(\frac{Z}{d}\right)^{\pi / \beta} \sin \left(\frac{\pi}{\beta} \phi\right)
$$

Sebagai perbandingan data analitik, dilakukan simulasi numerik yang dilakukan dengan menggunakan Sentaurus Structure Editor dan Sentaurus Device. Kedua program ini masingmasing digunakan untuk membangun struktur elektroda segitiga dan menyelesaikan persamaan Laplace. Sentaurus Device menggunakan metode 
Bank-Rose non-linear untuk menyelesaikan persamaan Laplace secara self-consistent. Mesh yang digunakan ditetapkan antara 0,5 dan $1 \mathrm{~nm}$ untuk area yang dekat elektroda segitiga, serta 1 hingga $5 \mathrm{~nm}$ di tempat lain. Strategi meshing ini diimplementasikan untuk mendapatkan hasil distribusi potensial yang halus tanpa menempatkan beban yang berat pada memori komputer. Disamping definisi mesh, optimasi juga dilakukan dengan cara menetapkan rentang konvergensi. Dalam simulasi ini, kontrol kesalahan relatif yang kami gunakan adalah $10^{-5}$. Hasil simulasinya ditampilkan pada Gambar 4. Penggunaan mesh yang lebih rapat dapat memberikan distribusi potensial yang lebih halus pada ujung segitiga.
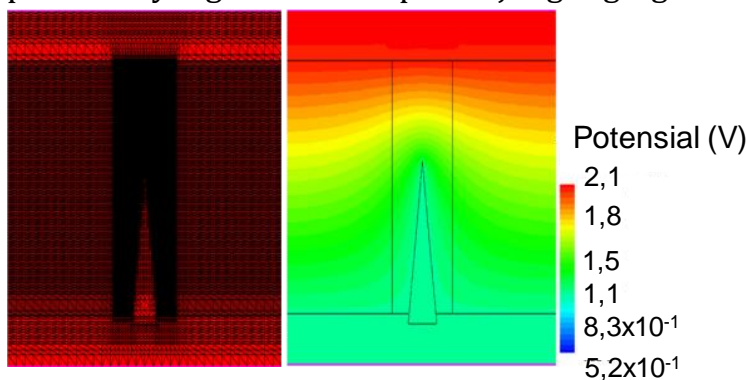

Gambar 4. Struktur simulasi dengan jumlah mesh yang berbeda (kiri) dan profil potensial dua dimensi (kanan).

\section{Pembahasan}

Persamaan (13) dievaluasi untuk $d=20 \mathrm{~nm}$ dan sudut bukaan $\theta=18^{\circ}$ dan $\theta=20^{\circ}$ [22]. Profil potensial diambil pada arah tegak lurus terhadap ujung kerucut. Kedua profil potensial listrik dapat dilihat pada Gambar 5. Dari gambar tersebut dapat terlihat bahwa perbedaan sudut bukaan ini memberikan perbedaan nilai potensial listrik yang tidak signifikan. Jika kita hitung root mean square (RMS) dari perbedaan nilai kedua grafik, akan kita dapat RMS sebesar 0,001 Volt.

Hal ini dikarenakan program Sentaurus menerapkan perlakuan khusus untuk elektroda yang bersentuhan langsung dengan isolator. Dalam hal ini, Sentaurus akan menghitung tegangan bias pada elektroda yaitu,

$$
\varphi=\varphi_{F}-\Phi_{M}
$$

dimana $\varphi_{F}$ merupakan potensial elektrode Fermi yang sama dengan tegangan yang diberikan dalam kasus elektroda/kontak antarmuka non-resistif. Sedangkan $\Phi_{M}$ adalah perbedaan fungsi kerja antara elektroda (polisilikon $\mathrm{n}^{+}$) dan semikonduktor intrinsik (silikon).
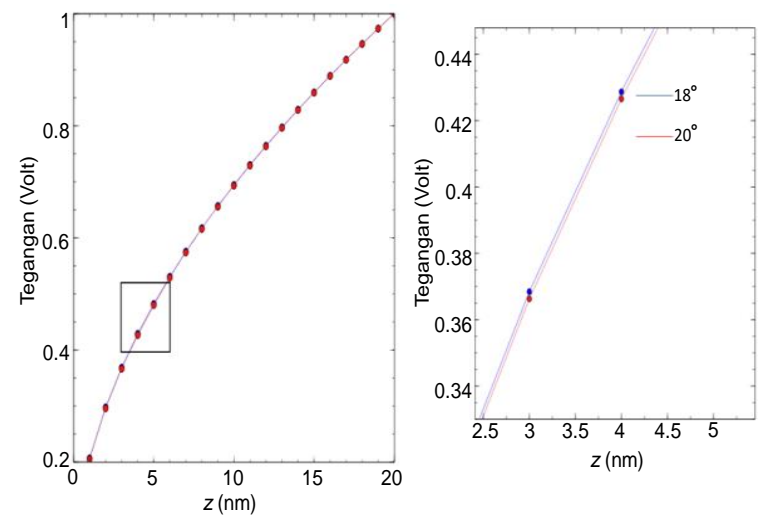

Gambar 5. Profil potensial yang dimodelkan secara analitik untuk model kerucut runcing dengan $\theta=18^{\circ}$ dan $\theta=20^{\circ}$.

$\Phi_{M}$ dapat dihitung dengan terlebih dahulu menentukan fungsi kerja polysilicon $\mathrm{n}^{+}\left(\Phi_{n^{+}}\right.$oly $)$. $\Phi_{n^{+} \text {poly }}$ berkaitan dengan konsentrasi doping oleh persamaan:

$$
\Phi_{n^{+} \text {poly }}=\Phi_{\text {poly }}-k T \ln \left(\frac{N_{D}}{n_{i}}\right)
$$

sehingga diperoleh,

$$
\Phi_{M}=\Phi_{n^{+} \text {poly }}-\Phi_{\text {poly }}=-k T \ln \left(\frac{N_{D}}{n_{i}}\right)
$$

Dengan menyelesaikan persamaan (15) dan (16), akan diperoleh nilai $\Phi_{n^{+} \text {poly }}$ dan $\Phi_{M}$ sebesar 4,15 dan -0,55 eV. Dengan menggunakan kedua nilai tersebut, profil potensial dikoreksi dengan menggunakan persamaan (14), sehingga persamaan (5) menjadi:

$$
U_{(z)}=\Phi_{F G}-\chi_{I}-e \varphi_{(z)}-\Phi_{M}
$$

Profil pita konduksi di sepanjang oksida pada $z=0.05$ (yakni pada ujung runcing), pada tegangan 10 Volt dan nilai $\chi=0,75 \mathrm{eV}$ [23] dapat dilihat pada Gambar 6. Gambar 6 menunjukkan hasil koreksi profil energi yang dihitung secara analitik. Terlihat bahwa hasil perhitungan analitik ini mirip dengan hasil perhitungan numerik dengan nilai RMS dari galat sebesar $0,24 \mathrm{eV}$. Terdapat sedikit perbedaan profil antara keduanya dikarenakan penggunaan persamaan (12) yang dihitung sampai orde pertama yang dilaporkan akurat untuk nilai $z / d$ kecil [20]. Namun dari perhitungan kami, untuk nilai $z / d$ yang kecil, hasil analitik dan numerik menghasilkan sedikit perbedaan profil. 


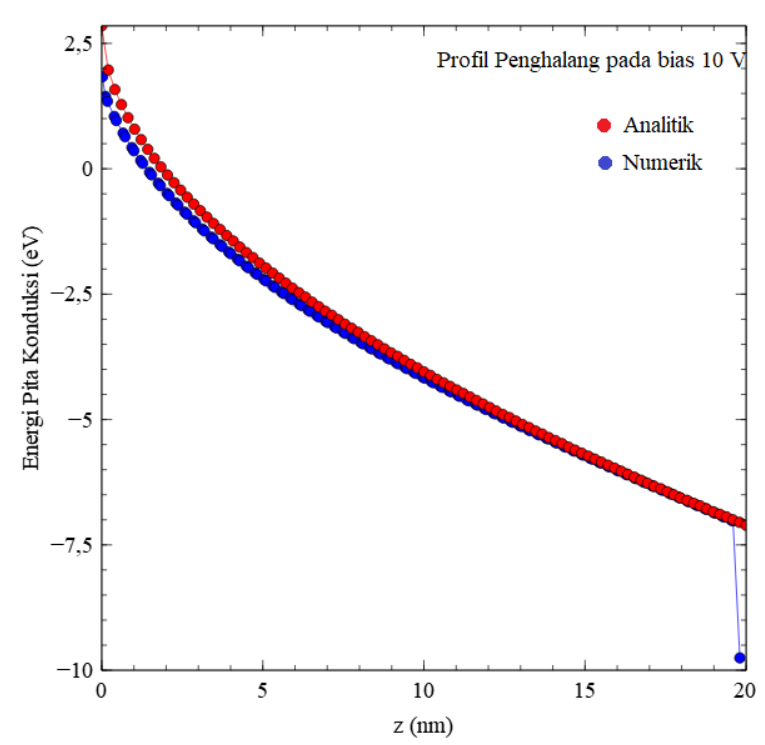

Gambar 6. Profil energi konduksi di sepanjang lapisan oksida.

Seperti dapat dilihat pada Gambar 6, hasil numerik memberikan nilai yang sedikit lebih rendah pada $z=0$ (yaitu pada permukaan elektroda) dibandingkan dari hasil analitik. Kami menemukan perbedaan ini terjadi akibat terbentuknya sumur kuantum di permukaan elektroda. Hal ini merupakan fenomena yang sama dengan ditemukan dalam MOSFET yang beroperasi dalam mode inversi. Sumur kuantum terbentuk karena akumulasi muatan pada permukaan elektroda. Geometri yang runcing menyebabkan akumulasi muatan terjadi pada tegangan bias yang lebih rendah daripada kasus untuk geometri planar. Simulasi kami tidak dapat memodelkan pembentukan sumur kuantum karena kami mengasumsikan bahwa penghalang segitiga dibuat dari bahan logam yang muatannya akan selalu terdistribusi di permukaan.

Sebaliknya, floating gate yang disimulasikan oleh Sentaurus, terbuat dari polisilikon dengan konsentrasi elektron yang tinggi dengan perilaku distribusi muatan yang berbeda dengan logam. Sumur kuantum dapat disimulasikan dengan menggunakan kalkulasi self-consistent [24] atau menyelesaikan persamaan Poisson 2D secara analitik [25]. Profil penghalang lengkap yang memperhitungkan sumur kuantum, ditampilkan pada Gambar 7. Keberadaan sumur kuantum ini berpotensi untuk mengurangi akurasi hasil perhitungan analitik terhadap hasil perhitungan numerik. Namun, sebagaimana yang terlihat dari Gambar 6, bahkan pada tegangan kerja 10 volt (yang merupakan tegangan kerja yang umum digunakan dalam pengoperasian flash memory), perbedaan perhitungan analitik terhadap numerik tetap kecil, ditandai dengan galat RMS yang kecil. Dengan kata lain, metode analitik ini masih valid untuk digunakan pada divais yang melibatkan elektroda runcing yang dioperasikan pada tegangan kerja tinggi. Secara umum terbentuknya sumur kuantum akibat pengaplikasian tegangan yang tinggi akan memunculkan elektron dengan keadaan terikat (bound states) atau semi terikat (quasi bound states). Elektron dalam keadaan semi terikat akan memiliki masa hidup tersendiri yang bergantung pada level energi elektron tersebut dan potensial perintang (potential barrier) sehingga masih mungkin mengalami fenomena terobosan. Sehingga secara kualitatif, terbentuknya sumur potensial beserta elektron terikat/semi-terikat berpotensi mengurangi arus terobosan, terlebih jika pengaplikasian tegangan pada divais dilakukan lebih pendek daripada masa hidup elektron semiterikat.

Gambar 8 menampilkan pengaruh sudut bukaan elektroda runcing, $\theta$, terhadap profil energi pita konduksi pada tegangan 10 volt. Nilai tegangan tegangan 10 volt dipilih karena bersesuaian dengan nilai tegangan penghapusan yang umum digunakan (10-12 volt). Sudut $\theta$ divariasikan antara $18^{\circ}$ hingga 90' (yang menunjukkan elektroda planar). Secara teoritis, $\theta$ akan mempengaruhi kerapatan muatan yang terakumulasi di ujung kerucut. Nilai $\theta$ yang lebih kecil menyebabkan peningkatan medan yang lebih tinggi dan mengakibatkan pembengkokan pita yang lebih besar.

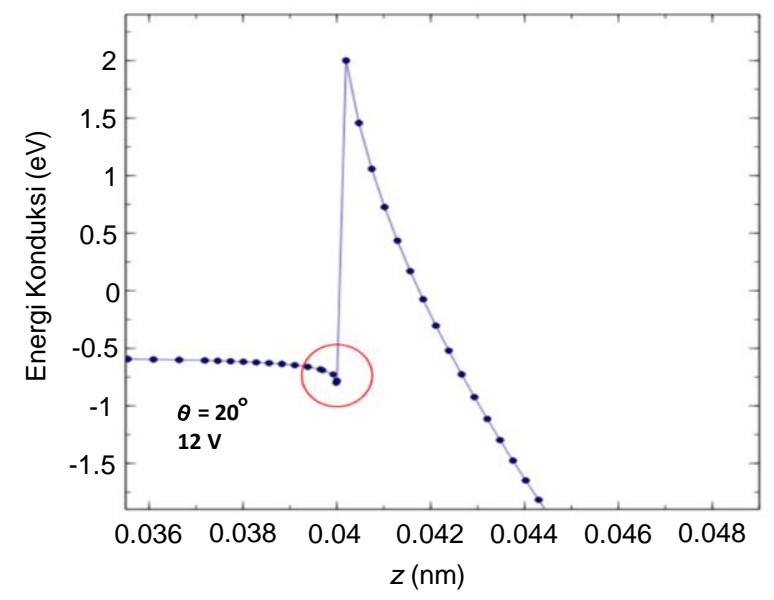

Gambar 7. Profil energi pita konduksi lengkap yang dihasilkan oleh Sentaurus Device menunjukkan pembentukan sumur kuantum (ditandai dengan lingkaran merah). 

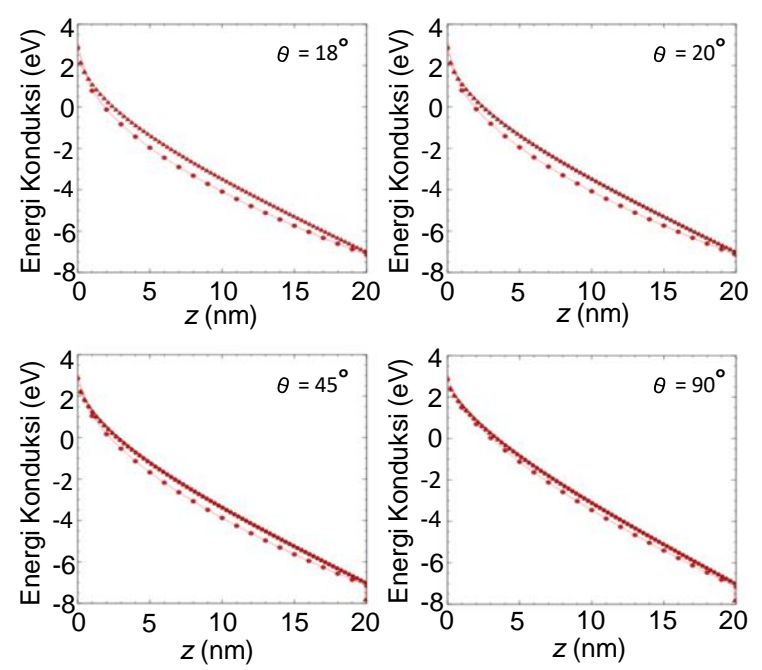

Gambar 8. Perbandingan hasil perhitungan secara analitik (simbol lingkaran) dan numerik (simbol garis) untuk profil energi konduksi pada tegangan $10 \mathrm{~V}$ untuk berbagai sudut bukaan $\theta$.

Dari gambar terlihat bahwa seiring dengan membesarnya nilai $\theta$, hasil data yang dihitung secara analitik sesuai dengan data yang dihitung secara numerik. Hal ini menunjukkan bahwa penggunaan persamaan (12) hingga orde pertama menghasilkan nilai yang kurang akurat untuk nilai $\theta$ yang kecil sehingga diperlukan perhitungan sampai orde yang lebih besar ketika memodelkan geometri kerucut dengan nilai $\theta$ yang kecil.

Pengaruh tegangan bias terhadap profil penghalang potensial ditampilkan pada Gambar 9. Secara umum, dapat terlihat dari persamaan (13) bahwa $\varphi_{(z)}$ berpengaruh secara linier dengan tegangan bias $V$. Oleh karena itu, untuk nilai $d, z$, and $\beta$ yang sama, penghalang potensial $U_{(z)}$ akan bergeser ke bawah secara linear seiring dengan meningkatnya tegangan bias $V$. Hal ini ditunjukkan pada Gambar 9 (A) yang menunjukkan perbandingan tiga profil $U_{(z)}$ (dengan tegangan yang diberikan adalah 10,11, dan 12 volt). Perlu dicatat bahwa sumur yang terbentuk cukup dangkal bahkan untuk variasi tegangan tertinggi (12 V). Dengan melihat profil penghalang energi yang dihasilkan, dapat diketahui bahwa meskipun profil energi yang dihasilkan sangat bengkok pada tegangan yang cukup tinggi $(10 \mathrm{~V})$, profil energi dalam rentang $E_{f} \leq E \leq \mathrm{U}_{(0)}$ akan menyerupai penghalang segitiga seperti dapat dilihat pada Gambar 9 (B).
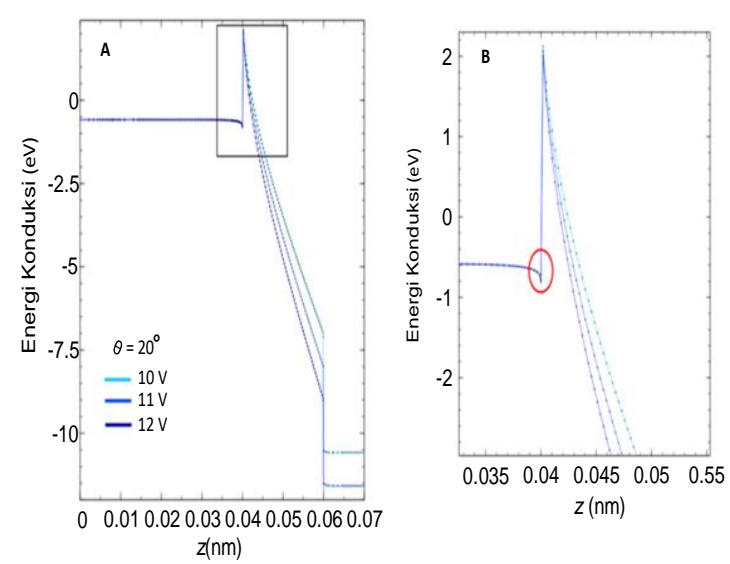

Gambar 9. Profil lengkap dari energi penghalang pada daerah tegangan bias tinggi (A) dan Profil yang diperbesar yang menunjukkan pembentukan sumur kuantum pada permukaan polisilikon (lingkaran merah) (B).

Untuk memeriksa keakuratan model, kami menggunakan formulasi potensial dan medan yang dihasilkan dalam pemodelan untuk menghitung rapat arus terobosan. Rapat arus terobosan dihitung dengan cara menurunkan persamaan (13) terhadap fungsi $z$ untuk mendapatkan medan listrik, $F$, dan kemudian digunakan dalam persamaan Fowler-Nordheim, JFN. Formulasi $F$ kemudian dituliskan sebagai berikut:

$$
\begin{gathered}
\vec{F}_{(z)}=-V\left(\frac{1}{d}\right)^{\frac{\pi}{\beta}} \sin \left(\frac{\pi}{\beta} \phi\right) \frac{\pi}{\beta}(z)^{\frac{\pi}{\beta}-1} \\
J_{F N}=\left(a F^{2}\right) \exp \left(-b F^{-1}\right)
\end{gathered}
$$

dengan $a$ dan $b$ adalah konstanta Fowler-Nordheim pertama dan kedua.

Kemudian, hasil yang kami diperoleh dibandingkan dengan salah satu dari hasil penelitian Kotov, dkk dari SST dalam Ref. [12] yang dihitung dengan ketebalan oksida yang berbeda yaitu, 20,10, dan $5 \mathrm{~nm}$. Dalam perhitungan kami, digunakan tinggi penghalang Polisilikon/oksida sebesar 3,15 eV dan massa efektif elektron sebesar $0,29 m_{\mathrm{o}}$ [26]. Perlu dicatat bahwa model kami tidak dapat digunakan untuk menghitung $J$ tepat di tepi ujung runcing (pada $z=0$ ) karena dengan memberikan nilai $z=0$ sehingga menghasilkan nilai $F$ tak hingga. Oleh karena itu, kami menghitung $J$ pada beberapa titik di dekat tepi. Setelah melakukan perhitungan dengan teliti, kami menemukan bahwa model kami memberikan hasil arus terobosan yang dekat dengan hasil SST ketika 
arus terobosan dihitung pada jarak $0,1 \mathrm{~nm}$ dari tepi segitiga, seperti yang ditampilkan pada Gambar 10 .

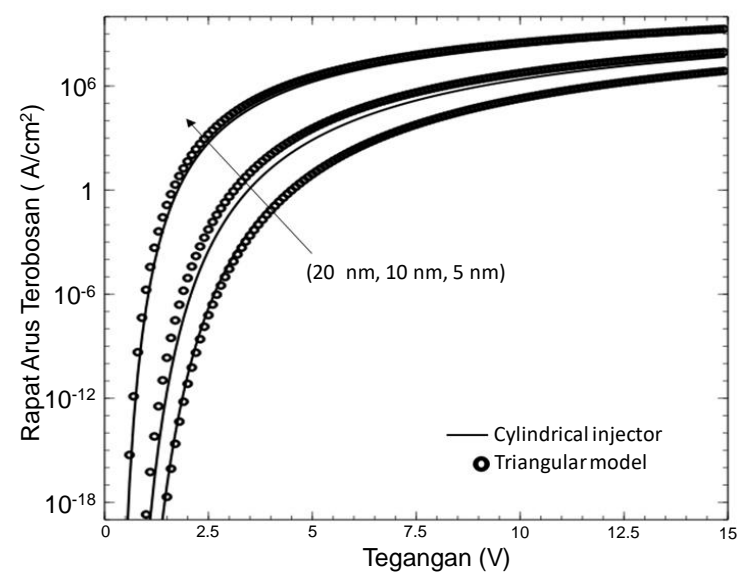

Gambar 10. Perbandingan rapat arus terobosan yang dihasilkan dari perhitungan model kami (simbol lingkaran) dengan hasil dari [12] (simbol garis lurus) pada variasi ketebalan oksida.

Pada Gambar 10 terlihat bahwa terdapat perbedaan hasil perhitungan rapat arus terobosan antara model kami dengan hasil dari Ref. [12] pada ketebalan oksida $10 \mathrm{~nm}$. Perbedaan ini terjadi karena perhitungan pada Ref. [12] menggunakan model geometris yang berbeda saat menurunkan formulasi medan listrik. Dalam pemodelan Ref. [12] floating gate runcing dimodelkan dengan bentuk silinder, bukan bentuk segitiga seperti pemodelan kami. Bentuk geometris yang berbeda ini akan menyebabkan formulasi medan listrik yang berbeda sehingga menyebabkan nilai rapat arus terobosan yang berbeda.

\section{Kesimpulan}

Potensial elektrostatik struktur floating gate runcing dalam sel memori split gate telah dimodelkan secara analitik dan numerik. Perbedaan asumsi mengenai bahan elektroda menyebabkan timbulnya sedikit perbedaan antara profil potensial hasil perhitungan analitik dengan profil potensial hasil perhitungan numerik. Pada perhitungan numerik menggunakan SYNOPSYS , elektroda diaset berbahan polisilikon $n+$ sehingga menimbulkan sumur kuantum di bagian ujung floating gate runcing. Namun kemudian dapat ditunjukkan bahwa pada tegangan operasi 10 Volt sekalipun, profil hasil perhitungan analitik masih mendekati hasil perhitungan numerik dengan galat RMS bernilai $0,24 \mathrm{eV}$. Potensial yang diperoleh kemudian digunakan untuk menghitung rapat arus terobosan. Profil potensial ini lalu digunakan untuk menghitung rapat arus terobosan. Dari hasil perhitungan diperoleh bahwa rapat arus terobosan yang dihitung menggunakan model kami memberikan hasil yang hampir sama dengan perhitungan yang diperoleh dari model injektor silinder yang digunakan oleh Kotov dkk. dari SST selaku produsen produk flash memory berbasis floating gate runcing

\section{Ucapan Terimakasih}

Penelitian ini didukung oleh hibah penelitian "Riset Desentralisasi PDUPT DIKTI" (nomor kontrak: 532 u/I1.C01/PL/2018) pada tahun 2018. Kami juga mengucapkan terima kasih kepada Pusat Mikroelektronika Institut Teknologi Bandung yang telah memfasilitasi dalam hal komputasi untuk kepentingan penelitian ini.

\section{Daftar Pustaka}

[1] Kahng, D. and Sze, S.M., A floating-gate and its application to memory devices, The Bell System Technical Journal, 46(4), pp. 12881295, 1967.

[2] Brewer, J.E., Introduction to Nonvolatile Memory, In Tewksburry, S.K. and Brewer, J.E, (Eds.), Nonvolatile Memory Technologies with Emphasis on Flash, $1^{\text {st }}$ ed., IEEE, pp. 1- 18, 2008.

[3] Bez, R., Camerlenghi, E., Modelli, A. and Visconti, A., Introduction to flash memory in Proceedings of IEEE, 91(4), pp. 489-502, 2003.

[4] Meena, J.S., Sze, S.M., Chand, U. and Tseng, T.Y., Overview of emerging nonvolatile memory technologies, Nanoscale Research Letter, 9(526), pp. 1-33, 2014.

[5] Gehring, A. and Selbelherr, S., Modelling of tunneling current and gate dielectric reliability for nonvolatile memory devices, IEEE Transaction on Device and Materials Reliability, 4(3), pp. 306-319, 2004.

[6] Van Houdt, J., Degraeve, D., Groesenken, G. and Maes, H.E., Physics of Flash Memory. In Tewksburry, S.K. and Brewer, J.E, (Eds.), Nonvolatile Memory Technologies with Emphasis on Flash, $1^{\text {st }}$ ed., IEEE, pp. 129-172, 2008.

[7] Forbes, R.G. Deane, J.H.B. Fischer, A. and Mousa, M.S., Illustrating field emission theory by using Lauritsen plots, Journal of Vacuum Science and Technology B, 31 02B102, pp. 16, 2013.

[8] Lenzlinger, M. and Snow, E.H., FowlerNordheim tunneling into thermally Grown $\mathrm{SiO}_{2}$, IEEE Transactions on Electron Devices, 15(9), pp. 686-687, 1968.

[9] Brand, K., Wu, S.P. and Chin, D., Novel read disturb failure mechanism induced by flash 
cycling, in IEEE International Reliability Physics Symposium, pp. 127-132, 1993.

[10] Mori, S., Kaeko, Y., Arai, N., Ohshima, Y., Araki, H., Narita, K., Sakagami, E. and Yoshikawa, K., Reliability study of thin interpoly dielectrics for nonvolatile memory application, in 28th Annual Proceeding on Reliability Physics Symposium, pp. 132-144, 1990.

[11] Moazzami R. and $\mathrm{Hu}, \mathrm{C}$. , Stress-induced current in thin silicon dioxide films, in IEEE International Technical Digest on Electron Devices Meeting, pp. 139-142, 1992.

[12] Kotov, A., Levi, A., Tkachev, T. and Markov, V., Tunneling phenomena in SuperFlash cell, in Proceeding of 2002 Non-Volatile Memory Technology Symposium, pp. 110-115, 2002.

[13] Markov, V., Liu, X., Kotov, A., Levi, A., Dang, T.N. and Tkachev, Y., SuperFlash Memory Program/Erase Endurance, in Proceeding of Non-Volatile Memory Technology Symposium, pp. 231-234, 2003.

[14] Liu, X., Markov, V., Kotov, A., Dang, T.N., Levi, A., Yue, I., Wang, A. and Qian, R., Endurance characteristics of SuperFlash Memory, in Proceeding of 8th International Conference on Solid-State and Integrated Circuit Technology, pp. 763-765, 2006.

[15] Tkachev, Y. Liu, X. and Kotov, A., Floating-gate Corner-enhanced Poly-to-poly Tunneling in Split-gate Flash Memory Cell, IEEE Transaction on Electron Device, 59(1), pp. 511, 2012.

[16] Saha, R., Bhowmick, B. and Baishya, S., Analytical Threshold Voltage and Subthreshold Swing Model for TMG FinFET, International Journal of Electronics, 106(4), pp. 553-566, 2018.

[17] Adekola, S.A. and Amusa, K.A., Effect of Ground Plane Dimension on Pattern Radiated by Slot Antennas, International Journal of Electronics, 106(9), pp. 1292-1319, 2019.

[18] Cabrera, H., De Pietro, L.G., Michaels, T., Thalmann, P., Ramsperger, U., Vandigni, A. and Abanov, A., Scale invariance of a diodelike tunnel junction, Physical Review B, 87 115436, pp. 1-6, 2013.
[19] Bouriaux, L.F., Rosamond, M.C., Williams, D.A., Davies, A.G. dan Walti, C., Field-enhanced direct tunneling in ultrathin ALD-grown Au$\mathrm{Al}_{2} \mathrm{O}_{3}-\mathrm{Cr}$ metal-insulator-metal structure, Physical Review B, 96 115435, pp. 1-11, 2017.

[20] Jackson, J D., Classical Electrodynamics, 3rd ed. J. Wiley \& Sons, pp. 76-77, 1999.

[21] Cabrera, H,. Zanin, D.A., De Pietro, L.G., Vandigni, A., Ramsperger, U. and Pescia, D., Looking for the origin of power laws in electric field assisted tunneling, in Proceedings of 2013 26th International Vacuum Nanoelectronics Conference, pp. 1-2, 2013.

[22] Kartiwa, G.M., Hendrayana, Y., Prihatiningrum, N., Sulthoni, M.A. and Idris, I., Effect LsG/LFG ratio variation to the $\mathrm{I}-\mathrm{V}$ curve of split-gate $1 \mathrm{st}$ generation SuperFlash, in Proceeding of Intl. Symposium on Electronics and Smart Devices, pp. 264-267, 2017.

[23] Fujimura, N., Ohta, A., Makihara, K. dan Miyazaki, S., Evaluation of valence band top and electron affinity of $\mathrm{SiO}_{2}$ and Si-based semiconductors using X-ray photoelectron spectroscopy, Japanese Journal of Applied Physics, 55 08PC06, pp. 1-6, 2016.

[24] Suryamas, A.B., Abdullah, M., Darma, Y. dan Khairurrijal., Sub Band States in a Nanometer Width Silicon Accumulation Layer/Vacuum Structure Obtained from Self-Consistent Solution of The Coupled Schrodinger-Poisson Equation, Indonesian Journal of Physics, 17 (1), pp. 15-20, 2006.

[25] Samuel, T.S.A., Balamurugan, N.B., Bhuvanerwari, S., Sharmila, D. dan Padmapriya, K., Analytical Modelling and Simulation of Single-Gate SOI TFET for Low Power Applications, International Journal of Electronics, 101 (6), pp. 779-788, 2014.

[26] Hadjadj, A., Simonetti, O., Maurel, T., Salace, G. dan Petit, C., $\mathrm{Si}_{-} \mathrm{SiO}_{2}$ Barrier Height and Its Temperature Dependence in Metal-OxideSemiconductor Structure with Ultrathin Oxide, Applied Physics Letters, 80(18), pp. 33343336, 2002. 